\title{
Homocystamide Conjugates of Human Serum Albumin as a Platform to Prepare Bimodal Multidrug Delivery Systems for Boron Neutron Capture Therapy
}

\author{
Tatyana Popova ${ }^{1,2} \mathbb{D}^{\mathrm{D}}$, Maya A. Dymova ${ }^{1} \mathbb{D}$, Ludmila S. Koroleva ${ }^{1} \mathbb{D}$, Olga D. Zakharova ${ }^{1} \mathbb{D}$, \\ Vladimir A. Lisitskiy ${ }^{1}$ D, Valeria I. Raskolupova ${ }^{1,2}$, Tatiana Sycheva ${ }^{3}$, Sergei Taskaev ${ }^{2,3} \mathbb{D}$, Vladimir N. Silnikov $^{1}$ \\ and Tatyana S. Godovikova ${ }^{1,2, *}$ \\ 1 Institute of Chemical Biology and Fundamental Medicine, SB RAS, 630090 Novosibirsk, Russia; \\ io197724@gmail.com (T.P.); maya.a.rot@gmail.com (M.A.D.); koroleva@niboch.nsc.ru (L.S.K.); \\ garonna3@mail.ru (O.D.Z.); foxvo.vl@gmail.com (V.A.L.); v.raskolupova@mail.ru (V.I.R.); \\ silnik@niboch.nsc.ru (V.N.S.) \\ 2 Faculty of Natural Sciences, Novosibirsk State University, 630090 Novosibirsk, Russia; taskaev@inp.nsk.su \\ 3 Budker Institute of Nuclear Physics, SB RAS, 630090 Novosibirsk, Russia; sychevatatyanav@gmail.com \\ * Correspondence: t_godovikova@mail.ru; Tel.: +7-383-3635-183
}

Citation: Popova, T.; Dymova, M.A.; Koroleva, L.S.; Zakharova, O.D.; Lisitskiy, V.A.; Raskolupova, V.I.; Sycheva, T.; Taskaev, S.; Silnikov, V.N.; Godovikova, T.S. Homocystamide Conjugates of Human Serum Albumin as a Platform to Prepare Bimodal Multidrug Delivery Systems for Boron Neutron Capture Therapy. Molecules 2021, 26, 6537. https:// doi.org/10.3390/molecules26216537

Academic Editor: Qiao-Hong Chen

Received: 30 September 2021

Accepted: 27 October 2021

Published: 29 October 2021

Publisher's Note: MDPI stays neutral with regard to jurisdictional claims in published maps and institutional affiliations.

Copyright: (C) 2021 by the authors Licensee MDPI, Basel, Switzerland. This article is an open access article distributed under the terms and conditions of the Creative Commons Attribution (CC BY) license (https:// creativecommons.org/licenses/by/ $4.0 /)$.

\begin{abstract}
Boron neutron capture therapy is a unique form of adjuvant cancer therapy for various malignancies including malignant gliomas. The conjugation of boron compounds and human serum albumin (HSA) - a carrier protein with a long plasma half-life-is expected to extend systemic circulation of the boron compounds and increase their accumulation in human glioma cells. We report on the synthesis of fluorophore-labeled homocystamide conjugates of human serum albumin and their use in thiol-'click' chemistry to prepare novel multimodal boronated albumin-based theranostic agents, which could be accumulated in tumor cells. The novelty of this work involves the development of the synthesis methodology of albumin conjugates for the imaging-guided boron neutron capture therapy combination. Herein, we suggest using thenoyltrifluoroacetone as a part of an anticancer theranostic construct: approximately 5.4 molecules of thenoyltrifluoroacetone were bound to each albumin. Along with its beneficial properties as a chemotherapeutic agent, thenoyltrifluoroacetone is a promising magnetic resonance imaging agent. The conjugation of bimodal HSA with undecahydro-closo-dodecaborate only slightly reduced human glioma cell line viability in the absence of irradiation ( $\sim 30 \mu \mathrm{M}$ of boronated albumin) but allowed for neutron capture and decreased tumor cell survival under epithermal neutron flux. The simultaneous presence of undecahydro-closo-dodecaborate and labeled amino acid residues (fluorophore dye and fluorine atoms) in the obtained HSA conjugate makes it a promising candidate for the combination imagingguided boron neutron capture therapy.
\end{abstract}

Keywords: boron neutron capture therapy; boron delivery agents; thenoyltrifluoroacetone; boronated albumin theranostic; conjugate; in vitro efficacy evaluation; irradiated by epithermal neutron flux; colony forming assay

\section{Introduction}

At present, cancer therapy includes surgery, chemotherapy, radiotherapy, targeted therapy, and immunotherapy. A newly emerging treatment option-boron neutron capture therapy (BNCT), in which drugs containing enriched boron are accumulated in tumor cells followed by their neutron beam radiation-offers an advantage over conventional chemo- and radiotherapies as it selectively targets tumor cells without significantly affecting healthy tissues. This is especially beneficial for clinical cases characterized by the infiltration of tumors into normal tissue or broad expansion of the tumor into the whole organ [1,2]. Clinical interest in BNCT has focused primarily 
on high-grade gliomas [3-6], patients with recurrent tumors of the head and neck region [7-14], which have failed conventional therapy, and a much smaller number of patients with cutaneous [15-18] or extra-cutaneous [19] melanomas. Currently, two BNCT drugs are available for clinical investigation: L-para-boronophenylalanine (BPA) and sodium mercaptoundecahydro-closo-dodecaborate (BSH), which is a derivative designed for brain tumor treatment. Despite their clinical use, both BPA and BSH show low selectivity, and great efforts have been made by several research groups to develop new and more selective boron delivery agents [20-25]. However, none of these have reached the stage where there is enough convincing data to warrant clinical biodistribution studies. More effective boron-containing agents are required so that they can be used alone or in combination with other agents to deliver the necessary amount of boron to cancer cells.

Human serum albumin (HSA) is one of the most suitable drug carriers [26-32]. Since the FDA approved Abraxane ${ }^{\circledR}$ (paclitaxel-encapsulated albumin formulation), HSA has attracted increasing attention for therapeutic applications. It offers advantages of biocompatibility, low toxicity, and versatility as it contains a number of accessible functional groups for conjugation with low-molecular-weight compounds including anticancer drugs. In addition, serum albumin can transport the bound molecules to a specific destination and allow for a controlled release of its cargo known as 'spatially controlled release' [26-31]. This is achieved due to albumin's interaction with specific receptors overexpressed in cancerous cells, which helps to specifically deliver albumin-bound molecules to tumor cells. Such receptors include glycoproteins Gp18, Gp30, and Gp60, as well as secreted protein acidic and rich in cysteine (SPARC) [33-36]. For example, the interaction of albumin molecules carrying paclitaxel with SPARC was shown to enable the increased local concentration of the drug released around the tumor cells. Likewise, the conjugation of boron-containing drugs with serum albumin would not only prolong the half-life of the drugs but also allow for the drug accumulation at the targeted tumor site [37-40]. Therefore, we chose serum albumin as a carrier for boron-based conjugates as potential anticancer therapeutics.

In order for BNCT to become a viable therapeutic option, the radiation dose delivered to the tumor must exceed the background radiation that healthy tissue receives from nonspecific neutron absorption [20]. As BNCT relies on neutron irradiation of the tumor-accumulated boron compounds for the therapeutic effect to occur, it is important to monitor the drug distribution inside the body in order to determine the optimal time window for the irradiation to be performed after drug administration. This can be achieved by introducing a tracking tag into the drug carrier. Examples of such tags include positron or gamma emitters that are incorporated into a nanoparticle-based drug delivering system. In this case, the drug distribution and localization can be monitored using positron emission tomography (PET) or single-photon emission computerized tomography (SPECT) imaging [41,42]. ${ }^{18} \mathrm{~F}$-BPA positron emission tomography (PET) imaging $[43,44]$ is now a well-established technique used as part of the treatment planning protocols both in Japan and Finland, the two countries where the largest number of patients have been treated by BNCT.

The emergence of hybrid scanners that allow for the simultaneous use of multiple imaging techniques (e.g., PET-CT (computed tomography), SPECT-CT, Optical-CT, MRI (magnetic resonance imaging)-PET, and MRI-Optical $[45,46]$ ) has advanced the development of multimodal imaging probes. Examples of such probes include bimodal probes, in which nuclear imaging techniques are combined with radio (CT, X-ray) or MR or optical imaging approaches [45]. At the same time, nuclear imaging requires ionizing radiation, which is hazardous and often short-lived. Therefore, alternative strategies for multimodal imaging are in demand.

${ }^{1} \mathrm{H}$ and ${ }^{19} \mathrm{~F}$ provide very sensitive nuclei for MRI [45]. Among many detection modalities, ${ }^{19} \mathrm{~F}$ MRI is advantageous for deep-tissue and noninvasive imaging in vivo [47-50]. In vivo experiments using the $\mathrm{C} 6$ rat glioma model demonstrated that ${ }^{19} \mathrm{~F}$ MRI in combination with ${ }^{1} \mathrm{H}$ MRI can selectively map the biodistribution of BPA labeled with an ${ }^{19} \mathrm{~F}$ 
atom $\left({ }^{19} \mathrm{~F}-\mathrm{BPA}\right)[50]$. The advantages of using the ${ }^{19} \mathrm{~F}$ nucleus include $100 \%$ abundance of the isotope and its high NMR sensitivity, which constitute $83 \%$ of that for a commonly used NMR nucleus- ${ }^{1} \mathrm{H}$. Moreover, our body lacks fluorinated compounds present at physiological concentrations high enough to be detected with ${ }^{19} \mathrm{~F}$ MRI (a typical detection limit is less than $10^{-3} \mu \mathrm{mol} / \mathrm{g}$ wet tissue weight) [47]. As a result, a low endogenous background enables externally introduced fluorinated anticancer agents to be detected using ${ }^{19} \mathrm{~F}$ MRI with high contrast-to-noise ratio and specificity [48,49].

MRI advantages can be further enhanced if combined with optical imaging (OFI) [45,51]. Such a combination enables more detailed 3D information regarding the anatomy of the body in addition to selective and sensitive information regarding biodistribution of the administered agents available in real-time. At the same time, it is challenging to develop MRI/optical bimodal probes characterized by a similar level of sensitivity for their magnetic and optical constituents. A general strategy is to use the MRI probe in excess over the optical probe. Using such a multifunctional protein as human serum albumin offers a potential solution to that challenge.

The amine and sulfhydryl groups in albumin could be used for HSA modification [52-54]. The site-directed fluorophore labeling of albumin can be performed on the single free thiol group at cysteine $34[48,52]$. There are as many as 59 lysine residues in albumin [53], providing 59 amine groups as potential modification sites by ${ }^{19} \mathrm{~F}$ MRI labels $[48,54,55]$. Earlier, our group synthesized a fluorinated $N$-trifluroacetyl homocysteine thiolactone (HTLAc) [48] that readily and irreversibly reacts with $\varepsilon$-amino groups of albumin's lysine residues. Three copies of trifluoroacetate and a single copy of a fluorophore $\mathrm{Cy} 5$ were covalently attached to a protein via suitable amino acids. For the synthesis of an albumin-based theranostic agent HSA-Cy5-HcyTFAc- $\mathrm{B}_{12} \mathrm{H}_{11}$, we used the reactivity of a thiolactone (a cyclic thioester) as a latent thiol functionality in thiol-'click' chemistry. The thiol was released by nucleophilic ring-opening (aminolysis) by amino groups on the HSA and subsequently reacted with a thiol 'scavenger' (a maleimide derivative of the undecahydro-closo-dodecaborate) [56] (Figure 1, arrow c).

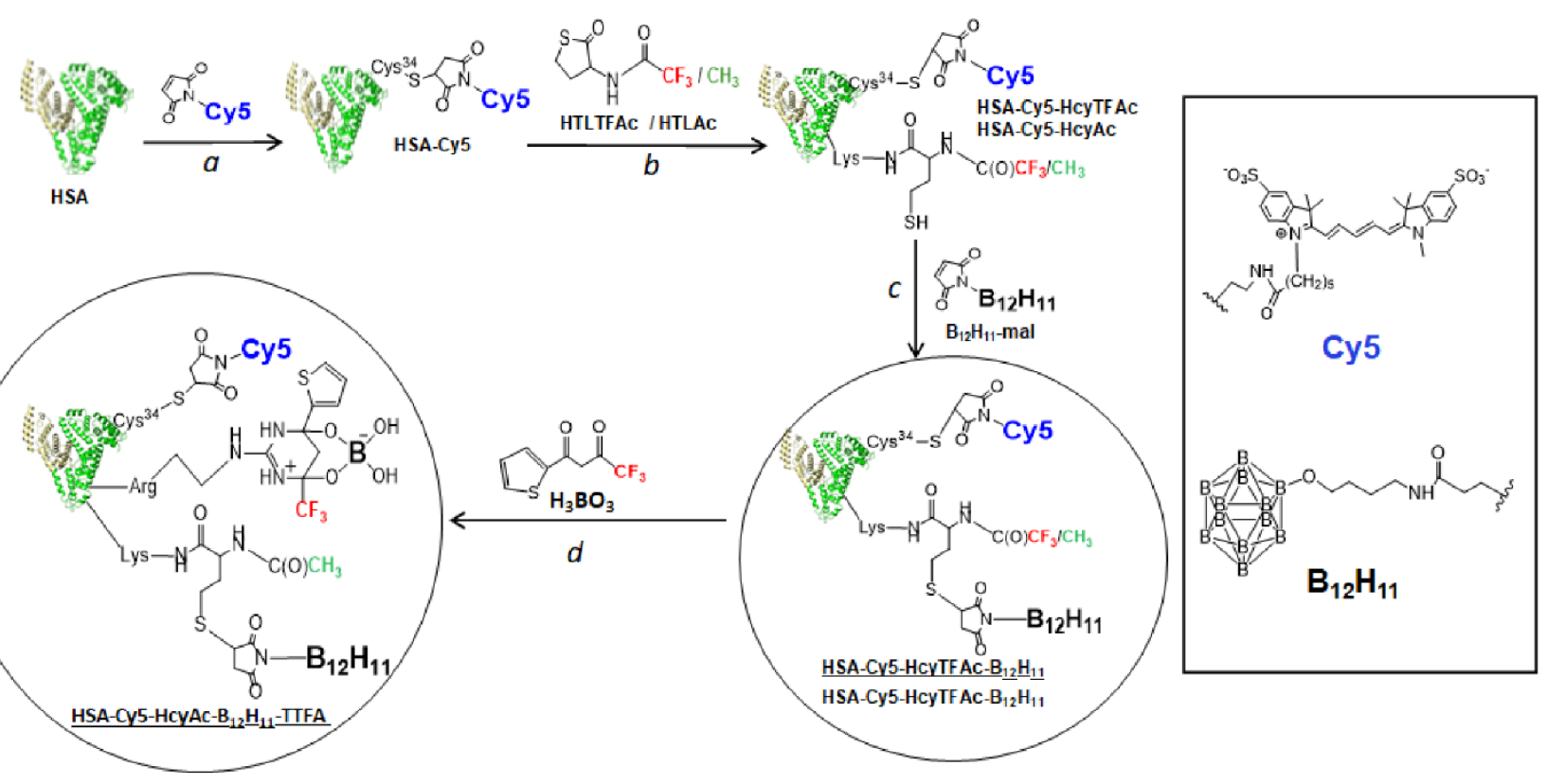

Figure 1. Synthetic routes to obtain the multifunctionalized serum albumin architecture-HSA-Cy5-HcyTFAc- $\mathrm{B}_{12} \mathrm{H}_{11}$ and HSA-Cy5-HcyAc- ${ }_{12} \mathrm{H}_{11}$-TTFA. Drug carrier (shown schematically as a heart-like structure)—human serum albumin (HSA). Effector- $\mathrm{B}_{12} \mathrm{H}_{11}$ : therapeutic agent. Note that homocysteine thiolactone derivatives (HTLTFAc and HTLAc) are used as a functional handle. HTLTFAc and TTFA are used as a source of fluorine atoms. Optical imaging-fluorescent dye Cy5 conjugated with Cys-34. 
Albumin also has 24 arginines [53] that, along with the lysines, could potentially be involved in the formation of a bimodal albumin-conjugate. The modification of arginine residues using dicarbonyl compounds is a common method to identify functional or reactive arginine residues in proteins [57]. In this work, we suggest the use of thenoyltrifluoroacetone (TTFA) as a part of the anticancer theranostic construct HSA-Cy5-HcyAc$\mathrm{B}_{12} \mathrm{H}_{11}$-TTFA (Figure 1, arrow d). A trifluoromethyl moiety of the construct brings several advantageous properties, including narrow NMR signal due to the free rotation of the group even within high-molecular complexes, single signal for the three fluorine atoms, which allows one to avoid artifacts, and the absence of fluorine signals splitting on ${ }^{1} \mathrm{H}$ nuclei in proximity. The latter property is particularly important as it prevents the loss of sensitivity and heating of biological samples to implement ${ }^{1} \mathrm{H}$ decoupling in the ${ }^{19} \mathrm{~F}$ detected spectrum.

Along with its beneficial properties as an imaging agent, TTFA is a promising chemotherapeutic agent. TTFA, an inhibitor of mitochondrial electron transport chain complex II, prevented the effects of hyperglycemia [58]. Hyperglycemia has been shown to promote cell proliferation, and tumor invasion and migration, along with increased chances of drug-resistance, which results in increased cancer prevalence and mortality [59]. By conjugating TTFA with albumin, the therapeutic index of the drug can be greatly improved, as the protein protects TTFA from renal clearance and, therefore, prolongs its circulation half-life. In addition, the enhanced permeation and retention effect of the macromolecular drug will allow preferential accumulation of the drug in tumor tissues. It will contribute to the local drug uptake. Therefore, we have proposed that the value of HSA as a BNCT drugs carrier may significantly increase if the TTFAlabeled homocystamide conjugate of human serum albumin is used for targeting. An HSA-based multidrug delivery system may represent an innovative delivery method for cancer therapeutics. As single drug-based therapeutic approaches may be compromised due to the mechanisms of intrinsic or acquired drug resistance [60,61], combination therapy allowing for a synergistic action of multiple anticancer agents via different signaling pathways appears as a potential solution $[62,63]$.

Below, the fluorine-labeling procedures, spectroscopic and ${ }^{19} \mathrm{~F}$ NMR characteristics of the obtained boronate albumin conjugates, and comparative analysis of different homocystamide albumin conjugates for the glioma cells' cytotoxicity are reported, together with preliminary examinations of biological behavior in vitro, such as boronated conjugate cytotoxicity before and after irradiation by epithermal neutron flux.

\section{Results}

\subsection{Conjugation to Human Serum Albumin}

Derivatives of the closo-dodecaborate anion are promising agents for boron BNCT [64]. Thus, of the multiple proposed strategies to introduce functional groups into the closo-dodecaborate anion, maleimide-dependent functionalization seems to be a promising one. Maleimide reacts with sulfhydryl groups of cysteine and homocysteine under mild conditions. This reaction has been used for the rapid assembly of a variety of albumin conjugates by so-called thiol-'click' chemistry [37-39,49,56,65]. For this reason, a maleimide derivative of the closo-dodecaborate anion $\left(\mathrm{B}_{12} \mathrm{H}_{11}\right.$-mal) would be a potentially useful precursor for further direct conjugation of the drug to

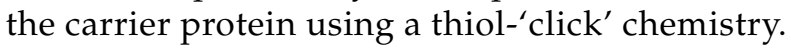

HSA has 35 cysteine residues: 34 are paired in 17 disulfide bonds, leaving only Cys34 available for site-specific chemical modification [53]. Researchers [37-39] have developed maleimide-containing closo-dodecaborate (MID) and aimed to conjugate it to albumin at Cys34. However, MID was found to conjugate not only to free SH of cysteine residue but also to lysine residues in albumin. As maleimide bioconjugation chemistry has been essentially linked with the construction of well-defined therapeutics, issues related with lysine cross-reactivity and heterogeneous preparations of albumin-drug conjugates have inspired us to develop a next generation of maleimido-type Michael acceptors. 
For the synthesis of the albumin-based HSA-Cy5-HcyTFAc- $\mathrm{B}_{12} \mathrm{H}_{11}$, we first labeled HSA with a fluorophore Cy5, whose strong fluorescence would enable the monitoring of internalization of the HSA conjugates into cells [48]. For the labeling strategy, a conventional maleimide chemistry was employed to position the fluorophore at Cys34 of the protein (Figure 1, arrow a). Next, we used the reactivity of a thiolactone (a cyclic thioester) as a latent thiol functionality in the thiol-'click' chemistry to establish additional SH groups into the protein conjugate. The use of the trifluoroacetyl derivative of homocysteine thiolactone (HTLTFAc) at this stage provided a convenient route to introduce fluorine labels into the conjugate (Figure 1, arrow b). Ellman's test [66] showed the incorporation of $3.0 \pm 0.1$ sulfhydryl groups per protein molecule upon reacting HSA-Cy5 with HTLTFAc. Based on MALDI-TOF/TOF mass spectrometry analysis of the tryptic fragments of HSA-Cy5HcyTFAc, the HcyTFAc residues were attached to Lys-199, Lys-414, and Lys-557/560 of HSA (Supplementary Materials Table S1).

The thiol was released via nucleophilic ring-opening (aminolysis) by amino groups on HSA and subsequently reacted with a thiol 'scavenger' (a maleimide derivative of the drug), as depicted in Figure 1, arrow c. All introduced SH groups were subsequently modified with $\mathrm{B}_{12} \mathrm{H}_{11}$-mal, as no free sulfhydryl groups were detected in the Ellman's test after the conjugation was complete.

It might be simply considered that the sensitivity in ${ }^{19} \mathrm{~F}$ NMR is easily improved by increasing the number of ${ }^{19} \mathrm{~F}$ nuclei in the probe. Albumin has 24 arginines [53] that, along with the lysines, could also potentially be involved in the formation of the bimodal albumin-conjugate. For the conjugate HSA-Cy5-Hcy-Ac- $\mathrm{B}_{12} \mathrm{H}_{11}$-TTFA, the introduction of fluorine was carried out by modifying arginine residues using TTFA (Figure 1, arrow d). The use of TTFA for the fluorination of albumin makes it possible to introduce almost twice as much fluorine into the protein structure as in the case of using HTLTFAc for this purpose. The presence of TTFA residue in the final conjugate was proven by the appearance of the characteristic maximum at $337 \mathrm{~nm}$ (Figure 2A). It was calculated that the constant absorbance value corresponded to an albumin preparation, which contained 5.4 TTFA residues per protein molecule.

The fluorine-labeled albumin conjugates were further characterized by ${ }^{19} \mathrm{~F}$ NMR. The ${ }^{19} \mathrm{~F}$ NMR spectra of the fluorinated conjugates are given in Figure 2B. The HSA-Cy5HcyTFAc- $\mathrm{B}_{12} \mathrm{H}_{11}$ and HSA-Cy5-HcyAc- $\mathrm{B}_{12} \mathrm{H}_{11}$-TTFA conjugates exhibited ${ }^{19} \mathrm{~F}$ signals at ca. 88 ppm.

The N-Hcy-HSA is more susceptible to oxidation than is HSA and the number of aggregates increases [67]. It was shown [48] that total oligomers increased to $83 \%$ in the samples of albumin containing unmodified $N$-homocysteine residues. At the same time, our results indicated that the blocking of the alpha-amino group of HTL can inhibit the aggregation of $\mathrm{N}$-homocysteinylated HSA. Our HSA-Cy5-HcyTFAc- $\mathrm{B}_{12} \mathrm{H}_{11}$ conjugate was $56.4 \%$ monomeric with $M_{W} \sim 66.5 \mathrm{kDa}$ and $39.6 \%$ oligomers, as shown by SDS-PAGE (Figure S3, lane 2, and Table S2). The modification can also affect protein conformation [48]. In order to evaluate the conjugation effect on the HSA secondary structure, we analyzed far-UV CD spectra of the intact and modified protein (Figure S4). Our results clearly demonstrated that the boronated albumin-based theranostic agent retained most of the $\alpha$-helices present in the native protein (Table S3).

Surprisingly, $N$-substituted HTL (HTLAc) appears to be a suitable starting material for medicinal chemistry. Its Hcy conjugate HSA-Cy5-Hcy Ac- $\mathrm{B}_{12} \mathrm{H}_{11}$-TTFA has been demonstrated to have beneficial physicochemical properties. We found that total oligomers decreased to $10 \%$ in the samples of albumin containing modified HcyAc residues (Figure S3, line 4, Table S2). $N$-acetyl HTL is a well-known protein-thiolating agent [68-71] and a drug used in liver therapy under the name citiolone due to its radical-scavenging properties. Despite the wide use of $N$-acetyl HTL, the cytotoxicity of its protein conjugates is not very well known. Therefore, more detailed studies with $\mathrm{N}$-substituted albumin homocystamide conjugates involving toxicity, metabolic rate, 
and immunologic consequences are necessary to establish their potential as multimodal probes for molecular imaging and anticancer therapy.

A

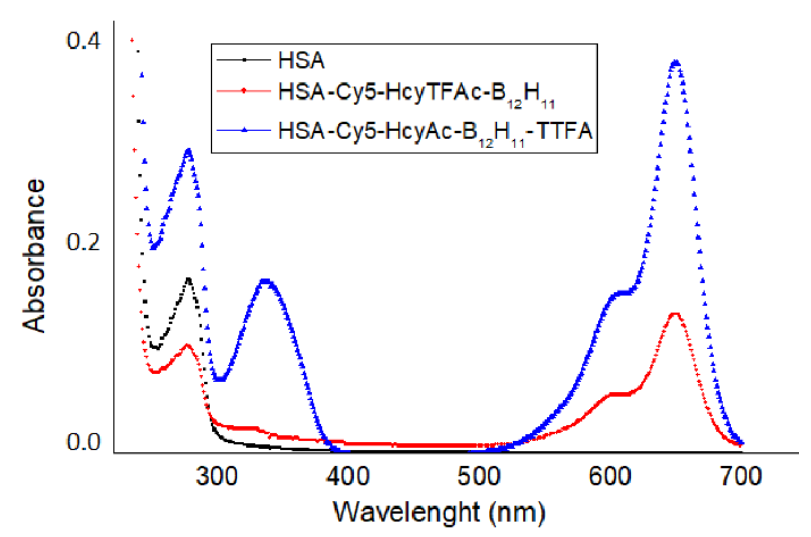

B

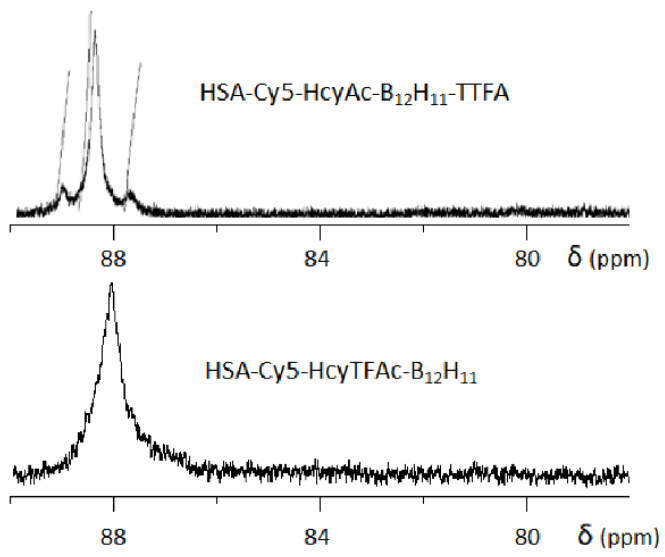

Figure 2. Characteristics of multifunctional human serum albumin conjugates. (A) UV-vis spectra of HSA and boronated albumin theranostic conjugates in PBS buffer, pH 7.4. HAS-black; HSA-Cy5-HcyTFAc- $\mathrm{B}_{12} \mathrm{H}_{11}$-red; HSA-Cy5-HcyAc- $\mathrm{B}_{12} \mathrm{H}_{11}$-TTFA-blue. (B) ${ }^{19} \mathrm{~F}$ NMR spectrum (at $282.4 \mathrm{MHz})$ of HSA-Cy5-HcyAc- ${ }_{12} \mathrm{H}_{11}$-TTFA $(0.6 \mathrm{mM})$ and HSA-Cy5-HcyTFAc- ${ }_{12} \mathrm{H}_{11}(0.3 \mathrm{mM})$ in PBS buffer ( $\mathrm{pH} 7.4$; to provide deuterium lock, $\mathrm{D}_{2} \mathrm{O}$ was added to $20 \%$ of the total volume) at $37^{\circ} \mathrm{C}$. The chemical shifts are referred to the resonance of $\mathrm{C}_{6} \mathrm{~F}_{6}$ at $0.0 \mathrm{ppm}$.

\subsection{In Vitro Studies}

The effect of HSA-Cy5-HcyTFAc- ${ }_{12} \mathrm{H}_{11}$ and HSA-Cy5-HcyAc- $\mathrm{B}_{12} \mathrm{H}_{11}$-TTFA conjugates on the viability of the cancer cells was determined by the standard colorimetric MTT assay [72] using T98G cells. In the absence of neutron irradiation, the cell line retained a proliferation rate of over $80 \%$ upon treatment with the boronated conjugate within its concentration range of $0.02-30 \mu \mathrm{M}$ (Figure 3). Thus, for neutron source efficacy evaluation, $\sim 30 \mu \mathrm{M}$ of boronated albumin can be used to minimize the effect of the drug on glioma cell colony formation.

The intracellular uptake, and accumulation and distribution of the boronated albumin theranostic conjugate were investigated by flow cytometry and confocal microscopy. The Cy5 fluorescent label (emission at $699 \mathrm{~nm}$ upon excitation at $633 \mathrm{~nm}$ ) was incorporated into the boron-albumin conjugate to enable monitoring of the conjugate in cells as far-red fluorescence does not overlap with cellular autofluorescence. Flow rate analysis showed that $98 \%$ of the T98G cells incubated with HSA-Cy5-HcyTFAc- $\mathrm{B}_{12} \mathrm{H}_{11}(20 \mu \mathrm{M})$ for $2 \mathrm{~h}$ accumulated the fluorescently labeled HSA derivative (Figure 4). The detailed kinetics of accumulation was not examined. At the same time, relative to the untreated cell control (left panel), $\sim 6 \%$ of cells were observed as fluorescent in the ' $0 \mathrm{~h}$ ' control, in which the cells 
were exposed to the HSA conjugate for $\sim 1$ min (middle panel), thus speaking in favor of the rapid cellular uptake of the conjugate.

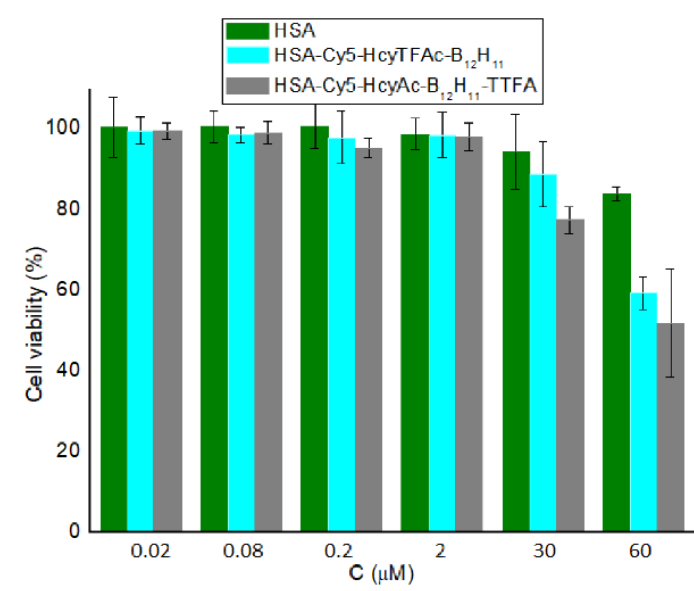

Figure 3. Viability of T98G cells. The cancer cell line was incubated for $72 \mathrm{~h}$ with HSA (green), HSACy5-HcyTFAc- $\mathrm{B}_{12} \mathrm{H}_{11}$ (cyan), and HSA-Cy5-HcyAc- $\mathrm{B}_{12} \mathrm{H}_{11}$-TTFA (gray) at various concentrations. After incubation, the cell viability was measured using the MTT test. The reported values represent the mean $\pm \mathrm{SD}(n=3)$. Two-way ANOVA was used for comparisons of more than two sets of data. Differences were considered to be significant if the $p$-value was $<0.05$.
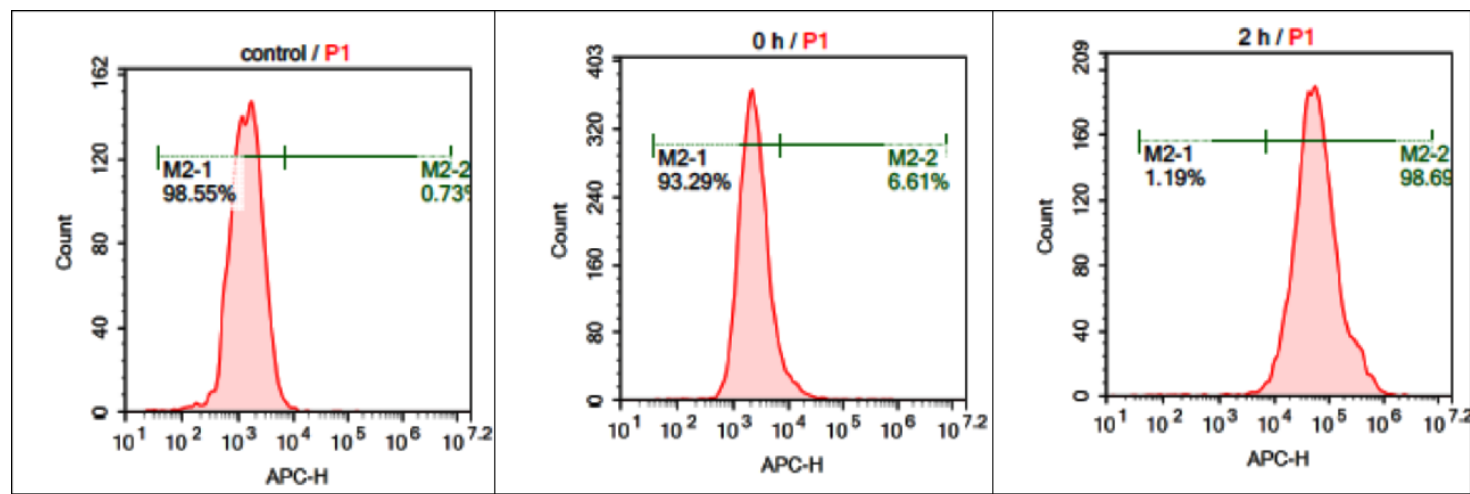

Figure 4. In vitro cellular uptake of HSA-Cy5-HcyTFAc- $\mathrm{B}_{12} \mathrm{H}_{11}$ by T98G cells measured by flow cytometry. Red color: FACS analysis; green color: percent cellular uptake of HSA-Cy5 and HSA-Cy5-HcyTFAc- $\mathrm{B}_{12} \mathrm{H}_{11}$. The data were normalized to nontreated cells (control).

For confocal microscopy analysis, the T98G cell line was incubated with the HSACy5-HcyTFAc- $\mathrm{B}_{12} \mathrm{H}_{11}$ conjugate $(20 \mu \mathrm{M})$ for $1.5 \mathrm{~h}$. The confocal microscopy images (Figure 5) showed the presence of the HSA-Cy5-HcyTFAc- $\mathrm{B}_{12} \mathrm{H}_{11}$ conjugate as punctuated small vesicles distributed in the cytoplasm of the T98G cells, suggesting an endocytic internalization mechanism $[73,74]$. Furthermore, orthogonal projections of z-stack acquisitions proved that vesicles and large endocytic structures were indeed present inside the treated cells (Figure 6).

\subsection{Neutron Irradiation Experiments}

Recently, several accelerators destined for hospital placement have been introduced [75]. For BNCT purposes, a proton accelerator with vacuum insulation and a lithium target have been developed at the Budker Institute of Nuclear Physics (BINP) at the Russian Academy of Sciences (Novosibirsk, Russian Federation) [76]. To date, initial radiobiological experiments on tumor cells to evaluate the efficacy of the neutron source at BINP have been performed with L-p-boronophenylalanine (BPA) $[77,78]$, a boron agent. In the current article, we provide an in vitro efficacy evaluation of this unique accelerator-based neutron source, for 
boron neutron capture therapy (BNCT) at BINP, using BPA and our albumin conjugate. We believe that our study will bring small clarity to the ongoing in vitro experiments on neutron capture therapy and help other researchers to advance accelerator-based BNCT into the clinical phase.
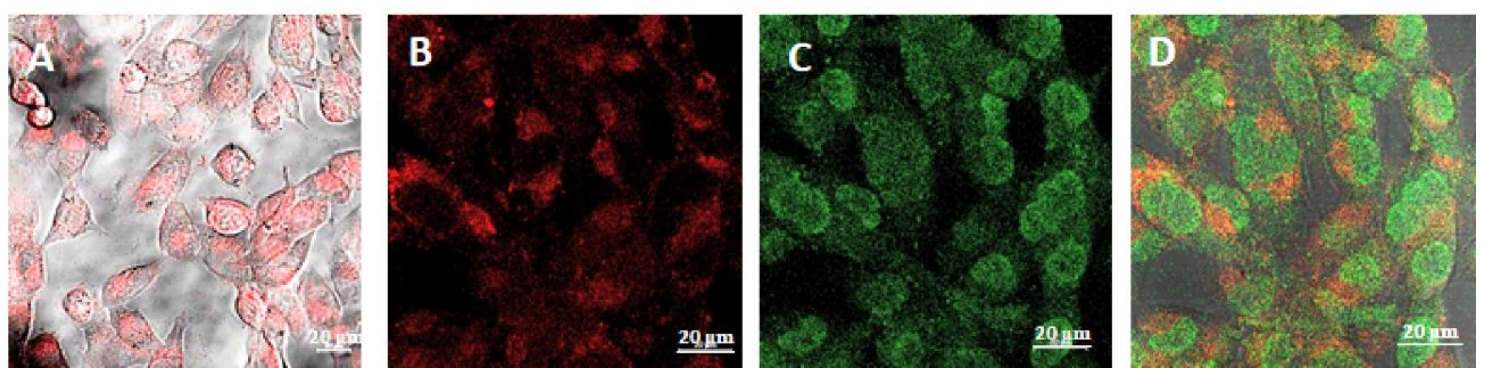

Figure 5. Representative images of confocal microscopy analysis of theT98G cell line treated with the fluorescent HSA-Cy5HcyTFAc- $\mathrm{B}_{12} \mathrm{H}_{11}$ conjugate $(20 \mu \mathrm{M})$ for $1.5 \mathrm{~h}$. Cell nuclei were stained with SYBR Green I. HSA-Cy5-HcyTFAc- $\mathrm{B}_{12} \mathrm{H}_{11}$ is visible as a red color. Scale bars: $20 \mu \mathrm{m}$. Panel (A): Live cell image: T98G cells were incubated with the conjugate for $1.5 \mathrm{~h}$ and washed three times with PBS. Panels (B-D): The cells were fixed with $2 \%$ formaldehyde. Panel (D): Merged (B,C).

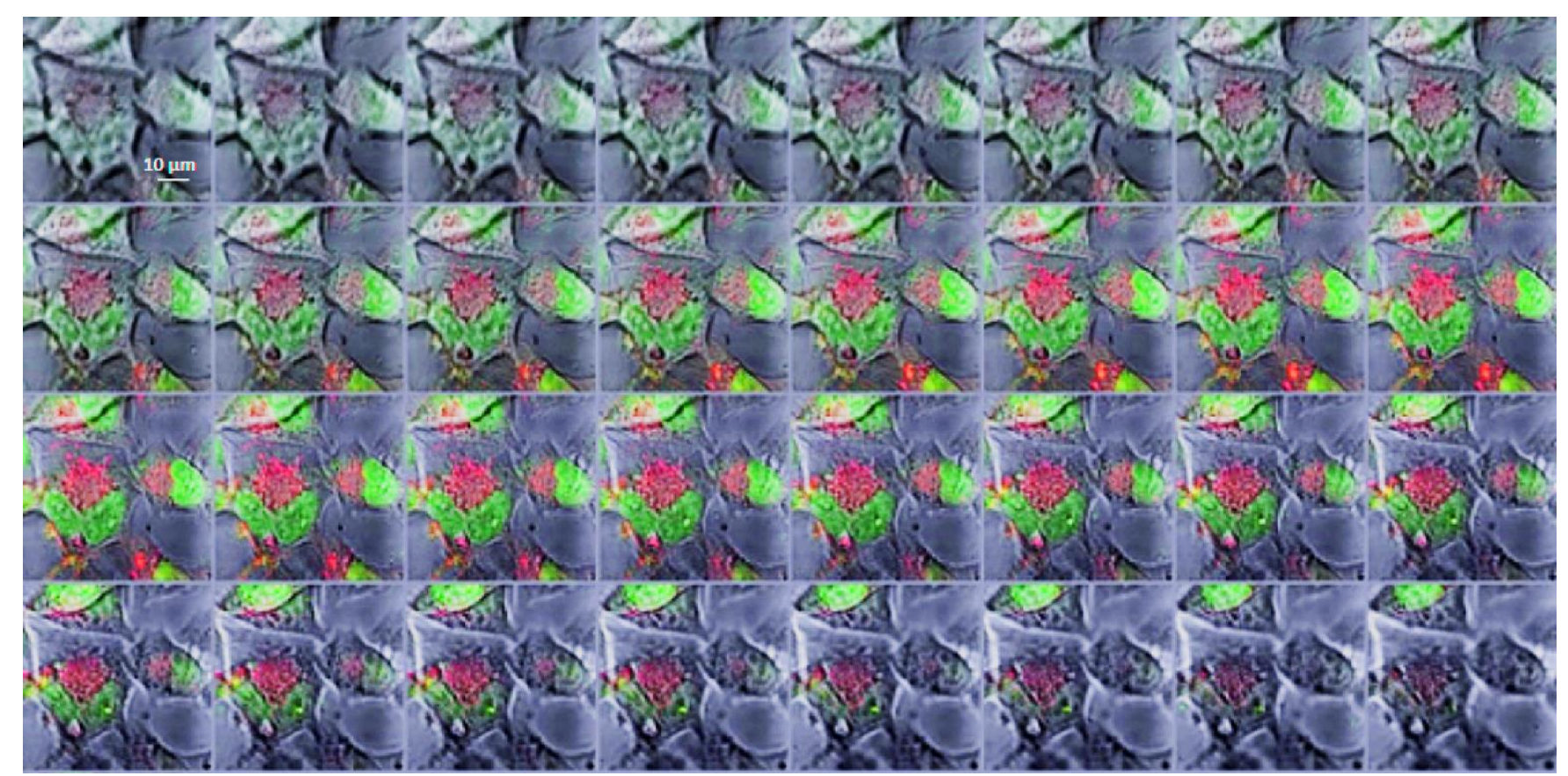

Figure 6. Gallery of merged images acquired along the z-axis of SYBR Green I-stained T98G cells treated with the HSA-Cy5Hcy-TFAc- $\mathrm{B}_{12} \mathrm{H}_{11}$ conjugate. Cell nuclei are visible as a green color. HSA-Cy5-HcyTFAc- ${ }_{12} \mathrm{H}_{11}$ is visible as a red color. Every subsequent image was taken $0.68 \mu \mathrm{m}$ higher than the previous one. Scale bars: $10 \mu \mathrm{m}$.

The glioma cells were incubated in medium with HSA-Cy5-HcyTFAc- $\mathrm{B}_{12} \mathrm{H}_{11}$ conjugate or with BPA and irradiated by an epithermal neutron flux. Boron-negative cells, irradiated by neutrons, were used as controls. Survival of the U87MG tumor cells incubated in medium with the HSA-Cy5-HcyTFAc- $\mathrm{B}_{12} \mathrm{H}_{11}$ conjugate or with BPA reduced with the increase of neutron flux (Figure 7). Survival data were fit by a linear regression according to the linear-quadratic formula (LQ fit) [79]. We did not receive any clones after the irradiation of U87MG cells with pretreatment BPA. Although the increase in neutron flux affected the survival of the cells without boron, pretreatment with HSA-Cy5-HcyTFAc- $\mathrm{B}_{12} \mathrm{H}_{11}$ or BPA resulted in a significantly lower fraction of the survived U87MG cells, as compared with the conjugate-free cells (Cntr) $(p<0.0001)$. Multiple comparisons by two-way ANOVA of 
the survived fractions did not show a statistical difference between the U87MG cell line pretreated with HSA-Cy5-HcyTFAc- $\mathrm{B}_{12} \mathrm{H}_{11}$ and BPA.

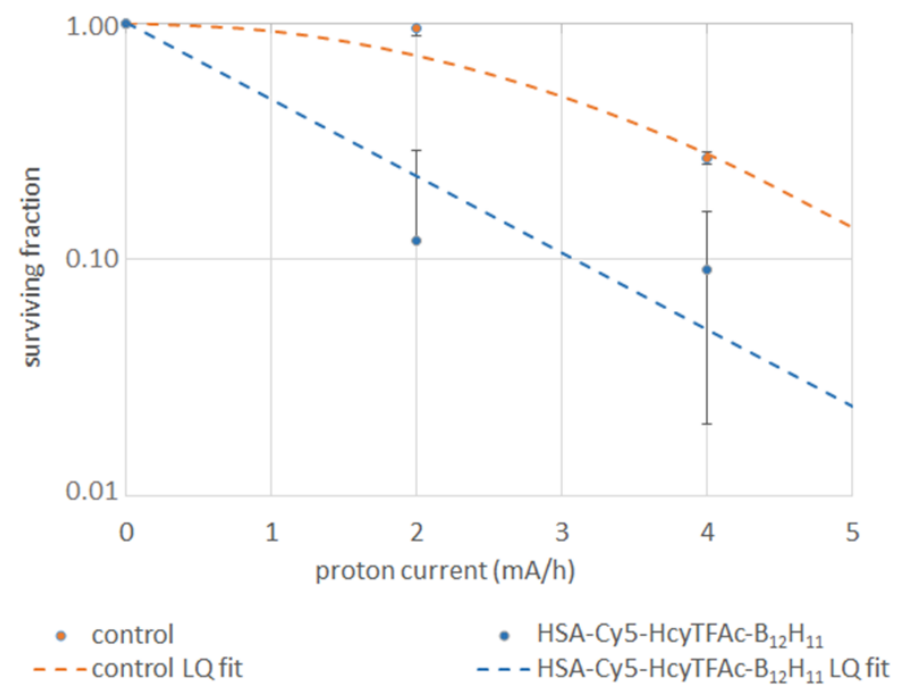

Figure 7. Survival curves of U87MG cells incubated with HSA-Cy5-HcyTFAc- $\mathrm{B}_{12} \mathrm{H}_{11}$ conjugate (cyan curve) and without reagents (orange curve) depending on neutron fluence.

The treatment with the HSA-Cy5-HcyTFAc- $\mathrm{B}_{12} \mathrm{H}_{11}$ conjugate and BPA before BCNT inhibited the proliferation of the U87MG cell line in a time-dependent manner (Figure 8). The colony-forming assay showed that a neutron flux of $4 \times 10^{12} \mathrm{~cm}^{-2}$ did not significantly affect cell viability without boron, but was effective in treating the tumor cells with boron accumulated. Our cell survival data confirmed the efficacy of the accelerator neutron source with the lithium target at BINP to produce a sufficient number of neutrons to initiate a boron neutron capture reaction within and in proximity to tumor cells. Decreasing the integral of the proton current to $3 m A \times h$ can mitigate the slight effect of irradiation on the control cells observed in some of the experiments.

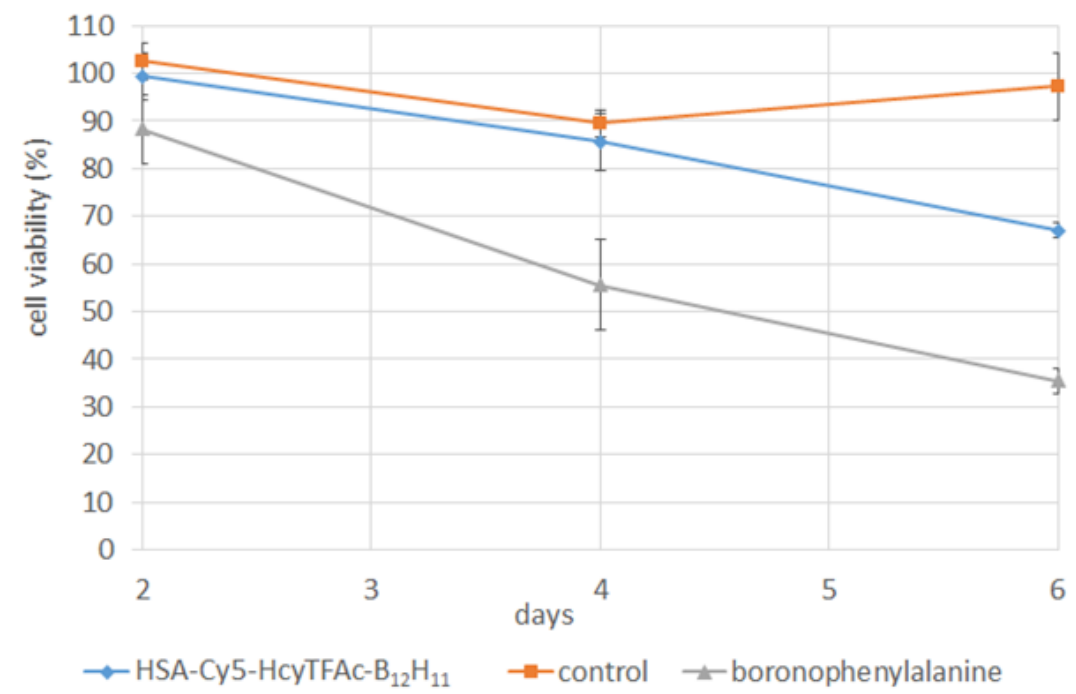

Figure 8. The cell viability of U87MG cells incubated with HSA-Cy5-HcyTFAc- $\mathrm{B}_{12} \mathrm{H}_{11}$ conjugate and BPA before BNCT at 2, 4, and 6 days after neutron irradiation. Control: U87MG cells after neutron irradiation without boron-containing compounds.

We performed initial in vitro experiments to evaluate the efficacy of the obtained conjugates. These data will be supplemented with the data obtained using appropriate animal models as a continuation of this study. 


\section{Materials and Methods}

\subsection{Chemicals, Reagents, Cancer Cells, and Facilities}

Human serum albumin (HSA) was obtained from Sigma-Aldrich Chem. Co. (St. Louis, MO, USA). The product number of HSA used was A3782. The SH contents of albumin and albumin products were determined using the Ellman's method as described in the literature at $\mathrm{pH} 8$, and employed DTNB (5,5'-dithio-bis(2-nitrobenzoic acid) spectrophotometrically at $412 \mathrm{~nm}\left(\varepsilon=1.36 \times 10^{4} \mathrm{M}^{-1} \mathrm{~cm}^{-1}\right)$ [66]. The concentrations of albumin solutions were determined by absorption at $292 \mathrm{~nm}, \mathrm{pH} 13$, using the molar extinction coefficient $\varepsilon=4.44 \times 10^{4} \mathrm{M}^{-1} \mathrm{~cm}^{-1}[53]$.

Reagents and materials were purchased from Sigma-Aldrich (St. Louis, MO, USA), unless otherwise indicated. MTT (3-[4,5-dimethylthiazol-2-yl]-2,5-diphenyltetrazolium bromide) assay kit was purchased from Invitrogen (Waltham, MA, USA). Milli-Q water with a conductivity greater than $18 \mathrm{M} \Omega / \mathrm{cm}$ was used in all experiments. Phosphatebuffered saline (PBS) (0.01 M, pH 7.3-7.5, Biolot) was used.

Human glioma cell lines: T98G and U87MG cells, were obtained from the Russian cell cultures collection (Russian Branch of ETCS, St. Petersburg, Russia). T98G cells were cultured in IMDM and DMEM growth media supplemented with $10 \%$ fetal calf serum (FCS), penicillin (100,000 IU/L), streptomycin (100,000 IU/L), and amphotericin B (1 mg/L) in a humidified atmosphere containing $5 \% \mathrm{CO}_{2}$ at $37^{\circ} \mathrm{C}$. U87MG cells were cultured at $37^{\circ} \mathrm{C}$ in $5 \% \mathrm{CO}_{2}$ in $\alpha$-MEM containing $10 \%$ fetal bovine serum (FBS), $1 \mathrm{mM}$ of sodium pyruvate, $50 \mathrm{U} / \mathrm{mL}$ of penicillin, and $100 \mathrm{~g} / \mathrm{mL}$ of streptomycin.

Electronic absorption spectra were acquired on a UV-1800 spectrometer (Shimadzu, Kyoto, Japan).

${ }^{19} \mathrm{~F}$ NMR spectra were recorded on an AV-300 NMR spectrometer (Bruker, Billerica, MA, USA) at $282.7 \mathrm{MHz}$. The spectra were detected at $25^{\circ} \mathrm{C}$ in $5 \mathrm{~mm}$ NMR sample tubes. $\mathrm{C}_{6} \mathrm{~F}_{6}(\delta 0.00 \mathrm{ppm})$ was used as an external reference for chemical shifts in ${ }^{19} \mathrm{~F}$ NMR spectra. Chemical shifts $(\delta)$ are reported in parts per million (ppm).

Inductively coupled plasma-atomic emission spectroscopy was performed using an ICPE-9820 (Shimadzu, Kyoto, Japan). A conjugate sample in PBS ( $40 \mu \mathrm{L}, 0.4 \mathrm{mM})$ was diluted to $4 \mathrm{~mL}$ with double-ionized water and used for measurement.

Confocal microscopy analysis was performed using an LSM 780 NLO (Zeiss, Oberkochen, Germany) on the basis of AxioObserver Z1 (Zeiss) at the Microscopy Center of the Institute of Cytology and Genetics, SB RAS, Russia.

\subsection{Synthesis and Characterization of Multifunctional Human Serum Albumin-Therapeutic Conjugates}

The maleimide-conjugating closo-dodecaborate tetramethylammonium form $\left(\mathrm{B}_{12} \mathrm{H}_{11}\right.$-mal) was synthesized according to the published procedures $[37,80]$ (see Supplementary Information).

The synthetic procedure for HSA-Cy5-HcyTFAc and HSA-Cy5-HcyAc conjugates was adapted from Chubarov et al. [48]. Detailed synthetic procedures are given in Supporting Information.

\subsubsection{Synthesis and Characterization of Theranostic Conjugate HSA-Cy5-HcyTFAc- $\mathrm{B}_{12} \mathrm{H}_{11}$}

A solution $(0.5 \mathrm{~mL}, 0.7 \mathrm{mM}, 0.35 \mu \mathrm{mol})$ of the HSA-Cy5-HcyTFAc in PBS buffer ( $\mathrm{pH}$ 7.4) was mixed with $\mathrm{B}_{12} \mathrm{H}_{11}$-mal in DMSO $(29.2 \mu \mathrm{L}, 1.58 \mu \mathrm{mol}, 0.166 \mathrm{M})$. The reaction mixture was incubated under constant gentle stirring at $37^{\circ} \mathrm{C}$ in the dark for $17 \mathrm{~h}$. The protein conjugate was purified by SEC utilizing a Millipore ultrafiltration tube and stored at $4{ }^{\circ} \mathrm{C}$. The yield of the HSA-Cy5-HcyTFAc- $\mathrm{B}_{12} \mathrm{H}_{11}$ derivative was $\sim 65 \%$. UV-vis (PBS buffer, $\mathrm{pH} 7.4): \lambda_{\max } 278 \mathrm{~nm}\left(\varepsilon=(3.88 \pm 0.1) \times 10^{4}\right), \lambda_{\max } 646 \mathrm{~nm}\left(\varepsilon=(4.99 \pm 0.1) \times 10^{4}\right)$. ${ }^{19} \mathrm{~F}$ NMR (PBS buffer, $\left.\mathrm{pH} 7.4, \mathrm{~d}, \mathrm{ppm}\right): \sim 88 \mathrm{ppm}\left(\mathrm{CF}_{3}\right.$, TFAc residues). Inductively coupled plasma-atomic emission spectroscopy: $2.8 \mathrm{~B}_{12} \mathrm{H}_{11}$ residues per albumin.

The molecular weight of the conjugate was determined by MALDI-TOF analysis, and differences in $M W$ were used to calculate the number of $\mathrm{B}_{12} \mathrm{H}_{11}$ bound per albumin. The HSA-Cy5-HcyTFAc- $\mathrm{B}_{12} \mathrm{H}_{11}$ conjugate had a calculated molecular mass of $68.203 \mathrm{kDa}$, and 
$34.101 \mathrm{kDa}$ for the double-charged protein (Figure S1). The difference between the homocysteinylated and native species is $2524 \mathrm{Da}$, which corresponds to three $N$-homocysteinyl$\mathrm{B}_{12} \mathrm{H}_{11}$ moieties, $N$-linked by amide linkages to Lys of HSA (N-Lys-HcyTFAc- $\mathrm{B}_{12} \mathrm{H}_{11}$; $586 \mathrm{Da})$ plus one dye moiety on Cys34 (S-Cys-Cy5; 766.4 Da).

3.2.2. Synthesis and Characterization of Multifunctional Human Serum Albumin-Therapeutic Conjugate HAS-Cy5-HcyAc- $\mathrm{B}_{12} \mathrm{H}_{11}$-TTFA

The HSA-Cy5-HcyAc- $\mathrm{B}_{12} \mathrm{H}_{11}$ synthesis was carried out in the same way as HSACy5-HcyTFAc- $\mathrm{B}_{12} \mathrm{H}_{11}$ synthesis. The yield of the HSA-Cy5-HcyAc- ${ }_{12} \mathrm{H}_{11}$ derivative was $\sim 65 \%$. UV-vis (PBS buffer, pH 7.4): $\lambda_{\max } 278 \mathrm{~nm}\left(\varepsilon=(3.88 \pm 0.1) \times 10^{4}\right), \lambda_{\max } 646 \mathrm{~nm}$ $\left(\varepsilon=(4.99 \pm 0.1) \times 10^{4}\right)$. Inductively coupled plasma-atomic emission spectroscopy revealed $1.8 \mathrm{~B}_{12} \mathrm{H}_{11}$ residue connections to an albumin molecule. The HSA-Cy5-HcyAc$\mathrm{B}_{12} \mathrm{H}_{11}$ conjugate had a calculated molecular mass of $67.250 \mathrm{kDa}$, and $33.625 \mathrm{kDa}$ for the double-charged protein (Figure S2). The difference between the homocysteinylated and native species is $1721 \mathrm{Da}$, which corresponds to two $\mathrm{N}$-homocysteinyl- $\mathrm{B}_{12} \mathrm{H}_{11}$ moieties, $N$-linked by amide linkages to Lys of HSA ( $N$-Lys-HcyAc- $\left.\mathrm{B}_{12} \mathrm{H}_{11} ; 532 \mathrm{Da}\right)$ plus one dye moiety on Cys34 (S-Cys-Cy5; 766.4 Da.

A solution $(0.213 \mathrm{~mL}, 0.71 \mathrm{mM}, 0.15 \mu \mathrm{mol})$ of the HSA-Cy5-HcyAc- $\mathrm{B}_{12} \mathrm{H}_{11}$ derivative in $0.1 \mathrm{M}$ of borate buffer ( $\mathrm{pH} 10.5)$ was mixed with TTFA in DMSO $(10.65 \mu \mathrm{L}, 1.68 \mu \mathrm{mol}$, $0.373 \mathrm{mg}$ ). The reaction mixture was incubated under constant gentle stirring at $37^{\circ} \mathrm{C}$ in the dark for $8 \mathrm{~h}$. The protein conjugate was purified by SEC utilizing a Millipore ultrafiltration tube and stored at $4{ }^{\circ} \mathrm{C}$. The yield of HSA-Cy5-HcyAc- ${ }_{12} \mathrm{H}_{11}$-TTFA was $\sim 95.6 \%$. UV-vis (PBS buffer, pH 7.4): $\lambda_{\max } 278 \mathrm{~nm}\left(\varepsilon=(3.88 \pm 0.1) \times 10^{4}\right), \lambda_{\max }=337 \mathrm{~nm}(\varepsilon=(2.17 \pm 0.1)$ $\left.\times 10^{4}\right), \lambda_{\max } 650 \mathrm{~nm}\left(\varepsilon=(4.99 \pm 0.1) \times 10^{4}\right) .{ }^{19} \mathrm{~F} \mathrm{NMR}\left(\mathrm{PBS}+\mathrm{D}_{2} \mathrm{O}, \delta, \mathrm{ppm}\right): 88.60\left(\mathrm{~s}, \mathrm{CF}_{3}\right)$. Inductively coupled plasma-atomic emission spectroscopy revealed 30 boron atoms bound to an albumin molecule.

\subsection{Cell Viability Assay (MTT Test)}

Cytotoxicity assays were performed using the MTT test, [72]. For this purpose, cells were grown to the exponential growth phase and seeded in 96-well plates to achieve a cell concentration of 2000 cells per well. The cells were incubated for $24 \mathrm{~h}$ prior to their treatment with the medium containing albumin conjugates to achieve HSA-equivalent concentrations ranging from 0.02 to $60 \mu \mathrm{M}$. The treatment of the cells with HSA derivatives was carried out for $72 \mathrm{~h}$ at $37^{\circ} \mathrm{C}$, after which MTT was added to achieve a $0.5 \mathrm{mg} / \mathrm{mL}$ final concentration. After incubation at $37{ }^{\circ} \mathrm{C}$ for $2 \mathrm{~h}$, the medium was removed, and $100 \mu \mathrm{L}$ of isopropanol was added to each well to dissolve formazan crystals. The plate was analyzed using a microplate reader Multiscan FC (Thermo Fisher Scientific Corporation) at the absorbance peak at $570 \mathrm{~nm}$ with the absorbance at $620 \mathrm{~nm}$ used as a baseline. The analysis of three independent experiments was carried out. The data are shown as mean values with standard deviations.

\subsection{Intracellular Distribution of Boronated Albumin Theranostic In Vitro}

T98G cells $\left(10^{5} / \mathrm{mL}, 100 \mu \mathrm{L}\right)$ were seeded in Thermo Scientific ${ }^{\mathrm{TM}}$ Nunc $^{\mathrm{TM}}$ MicroWell ${ }^{\mathrm{TM}}$ 96-Well Optical-Bottom Plates with a Coverglass Base, in IMDM containing 10\% FBS, penicillin, and streptomycin and were preincubated for $17 \mathrm{~h}$ in humidified atmosphere with $5 \% \mathrm{CO}_{2}$. The medium was exchanged for the fresh one containing $20 \mu \mathrm{M}$ of HSA-Cy5-HcyTFAc- $\mathrm{B}_{12} \mathrm{H}_{11}$. The cells were incubated at $37^{\circ} \mathrm{C}$ for $1.5 \mathrm{~h}$. Time-lapse images were sampled every 5 min over a period of $1.5 \mathrm{~h}$ on a LSM780 microscope (Zeiss, Oberkochen, Germany). Red fluorescence of Cy5 was detected at $699 \mathrm{~nm}$ upon excitation at $633 \mathrm{~nm}$. Then, the cells were washed 3 times with PBS and the intracellular localization of HSA was assessed by scanning fluorescence microscopy. Then, cells were fixed in $4 \%$ formaldehyde for $20 \mathrm{~min}$ at room temperature and counterstained by SYBR Green 1 (1:10,000). The intracellular distribution of HSA and SYBR Green 1-stained nuclei was observed by scanning fluorescence microscopy. Green fluorescence 
of SYBR Green 1 was detected at $571 \mathrm{~nm}$ upon excitation at $488 \mathrm{~nm}$ (band of Ar laser). The images were processed in the ZEN Blue light program.

\subsection{Flow Cytometry}

Flow cytometry was used to characterize the levels of intracellular accumulation of HSA-Cy5-HcyTFAc- $\mathrm{B}_{12} \mathrm{H}_{11}$ in T98G cells after 0 and $2 \mathrm{~h}$ of incubation. A number of $1 \times 10^{6}$ cells per well were seeded in 12-well plates and then detached by adding trypsin (2\%) (MP Biomedicals, Irvine, CA, USA). The cells were resuspended in DMEM, pelleted by centrifugation at $200 \mathrm{~g}$ for $5 \mathrm{~min}$, washed with PBS, and fixed with $2 \%$ formaldehyde in PBS buffer for $10 \mathrm{~min}$ at room temperature. The fixed cells were analyzed using a NovoCyte flow cytometer (ACEA Biosciences, Santa Clara, CA, USA) with the data processed using NovoExpress software (ACEA Biosciences, Santa Clara, CA, USA). Three independent experiments were performed for each of the conditions analyzed. Intracellular accumulation of albumin's derivatives was characterized by the percentage of fluorescently labeled cells and the mean fluorescence of the cells in a sample.

\subsection{Neutron Irradiation Experiments}

Neutron irradiation was carried out at Budker Institute of Nuclear Physics (Novosibirsk, Russia), using the accelerator-based neutron source [76]. After $18 \mathrm{~h}$ of incubation with the HSA-Cy5-HcyTFAc- $\mathrm{B}_{12} \mathrm{H}_{11}$ conjugate $(31 \mu \mathrm{M})$ or BPA-containing boron-10 $(20 \mathrm{ppm}, 10 \mu \mathrm{g} / \mathrm{mL})$, human glioma cells were irradiated by epithermal neutron flux over $2 \mathrm{~h}$. Boron-negative cells, irradiated by neutrons, were used as controls. The irradiation conditions were as follows: proton energy of $2.1 \mathrm{MeV}$, proton current of 1.5-3.0 mA to enable an epithermal neutron flux up to $3 \times 10^{8} \mathrm{~cm}^{-2} \mathrm{~s}^{-1}$. The neutron flux was measured by a gold foil activation technique using a detector with a lithiumcontaining scintillator (GS20, Saint-Gobain Crystals, Hiram, OH, USA). The neutron flux was set up at $4 \times 10^{12} \mathrm{~cm}^{-2}$ and $8 \times 10^{12} \mathrm{~cm}^{-2}$.

The cytotoxicity of the HSA-Cy5-HcyTFAc- $\mathrm{B}_{12} \mathrm{H}_{11}$ conjugate in BNCT was evaluated by colony forming assay [79]. After neutron irradiation, the cells were incubated at $37^{\circ} \mathrm{C}$ in a 5\% $\mathrm{CO}_{2}$ atmosphere for 8 days, fixed with glutaraldehyde, and stained with crystal violet, and colonies of more than 50 cells were counted. A cell proliferation assay was also performed after irradiation using an MTT assay. All cells were seeded in 96-well plates at a density of 1000 cells per well after irradiation. After 2, 4, or 6 days of incubation, proliferation of U87MG cells was assessed using a 3-(4,5-dimethylthiazol-2-yl)-2,5-diphenyl tetrazolium bromide (MTT) assay. The optical density was recorded using a microplate reader (Apollo LB 912, Berthold Technologies, Bad Wildbad, Deutschland) at $570 \mathrm{~nm}$, with a reference wavelength of $620 \mathrm{~nm}$. Two-way ANOVA was used for comparisons of more than two sets of data. Differences were considered to be significant if the $p$-value was $<0.05$.

\section{Conclusions}

Boron-albumin conjugates are promising anti-cancer therapeutics as they can be administered less frequently than alternative therapeutic agents and yet offer sufficient accumulation of the action component at the tumor site, which can improve the quality of life for cancer patients. We report successful preparation of a new albumin-based boron theranostic agents with multimodal functions, such as fluorescence imaging (Cy5) and ${ }^{19} \mathrm{~F}$ MRI ( $\mathrm{N}$-trifluoroacetylhomocysteine, or thenoyltrifluoroacetone residue). The use of TTFA for the fluorination of albumin makes it possible to introduce almost twice as much fluorine into the protein structure as in the case of using HTLTFAc for this purpose. We proposed that the value of HSA as a BNCT drugs carrier may significantly increase if the TTFA-labeled homocystamide conjugate of human serum albumin is used for targeting. Along with its beneficial properties as an imaging agent, TTFA is a promising chemotherapeutic agent. An HSA-based multidrug delivery system may represent an innovative delivery method for cancer therapeutics. The conjugation of albumin with undecahydro-closo-dodecaborate did not significantly affect cell viability 
in the absence of irradiation, as compared with the unmodified protein. However, neutron capture by this boron-containing albumin decreased the tumor cell survival. Conjugation of the boron-based drug to HSA-a carrier protein with a long plasma half-life-is expected to extend its systemic circulation and preserve its activity. The presence of fluoro-organic residues and a single copy of a fluorophore $\mathrm{Cy} 5$ will enable the monitoring of the drug distribution by two different modes, thus making the reported HSA conjugates a real theranostic tool.

Supplementary Materials: The following are available online, Details on the synthesis of $\mathrm{B}_{12} \mathrm{H}_{11^{-}}$ mal and HTLTFAc and spectroscopic data for all synthesized compounds; detailed synthetic procedures of HSA-Cy5-HcyTFAc and HSA-Cy5-HcyAc- $\mathrm{B}_{12} \mathrm{H}_{11}$ conjugates. Characterizations of multifunctional human serum albumin conjugates by MALDI-ToF spectra presented in Figures S1 and S2. Figure S3: SDS-PAGE analysis of HSA conjugates under denaturation condition (with DTT) using 7\% PAAG under Laemmli condition. Figure S4: Circular dichroism (CD) spectra of the unmodified HSA and multifunctional human serum albumin conjugates. Table S1: Identification of specific $N$-trifluorohomocysteinylation modification sites in HSA-Cy5-HcyTFAc conjugate, Table S2. Quantitative data of the SDS-PAGE analysis of HSA conjugates presented in Figure S3. Table S3. Secondary structures calculated by deconvolution of the CD spectra shown in Figure S4. Scheme S1-Synthesis of maleimide-functionalized closo-dodecaborate $\left(\mathrm{B}_{12} \mathrm{H}_{11}\right.$-mal), Scheme S2-HTLTFAc synthesis.

Author Contributions: Conceptualization, T.S.G. and V.N.S.; methodology, T.S.G., O.D.Z. and S.T.; synthesis of the conjugates, T.P., L.S.K. and V.I.R.; CD experiments, V.A.L.; investigation in vitro, O.D.Z. and M.A.D.; neutron irradiation experiments, T.S., M.A.D. and S.T.; resources, V.N.S.; writing of Experimental Section and Supplementary Materials, T.P., M.A.D. and L.S.K.; writing-review and editing, T.S.G.; supervision, V.N.S.; project administration, V.N.S. and S.T.; funding acquisition, V.N.S. All authors have read and agreed to the published version of the manuscript.

Funding: This research was funded by the Russian Science Foundation (grant №19-74-20123).

Institutional Review Board Statement: Not applicable.

Informed Consent Statement: Not applicable.

Data Availability Statement: Not applicable.

Acknowledgments: We thank the Joint Center for genomic, proteomic, and metabolomics studies (ICBFM SB RAS) for obtaining mass-spectra. We wish to thank Sergei I. Baiborodin for technical assistance and interpretation of confocal microscopy data (Microscopy Center of the Institute of Cytology and Genetics, SB RAS, Russia).

Conflicts of Interest: The authors declare no conflict of interest. The funders had no role in the design of the study; in the collection, analyses, or interpretation of data; in the writing of the manuscript, or in the decision to publish the results.

Sample Availability: Samples of the compounds HSA-Cy5-HcyTFAc- ${ }_{12} \mathrm{H}_{11}$ and HSA-Cy5-HcyAc$\mathrm{B}_{12} \mathrm{H}_{11}$-TTFA are available from the authors.

\section{References}

1. Barth, R.F.; Coderre, J.A.; Vicente, M.G.; Blue, T.E. Boron neutron capture therapy of cancer: Current status and future prospects. Clin. Cancer Res. 2005, 11, 3987-4002. [CrossRef] [PubMed]

2. Barth, R.F.; Zhang, Z.; Liu, T. A realistic appraisal of boron neutron capture therapy as a cancer treatment modality. Cancer Commun. 2018, 38, 36-42. [CrossRef] [PubMed]

3. Barth, R.F.; Mi, P.; Yang, W. Boron delivery agents for neutron capture therapy of cancer. Cancer Commun. 2018, 38, 35. [CrossRef] [PubMed]

4. Nakagawa, Y.; Pooh, K.; Kobayashi, T.; Kageji, T.; Uyama, S.; Matsumura, A.; Kumada, H. Clinical review of the Japanese experience with boron neutron capture therapy and a proposed strategy using epithermal neutron beams. J. Neurooncol. 2003, 62, 87-99. [CrossRef]

5. Miyatake, S.; Kawabata, S.; Kajimoto, Y.; Aoki, A.; Yokoyama, K.; Yamada, M.; Kuroiwa, T.; Tsuji, M.; Imahori, Y.; Kirihata, M.; et al. Modified boron neutron capture therapy for malignant gliomas performed using epithermal neutron and two boron compounds with different accumulation mechanisms: An efficacy study based on findings on neuroimages. J. Neurosurg. 2005, 103, 1000-1009. [CrossRef] [PubMed] 
6. Miyatake, S.; Kawabata, S.; Yokoyama, K.; Kuroiwa, T.; Michiue, H.; Sakurai, Y.; Kumada, H.; Suzuki, M.; Maruhashi, A.; Kirihata, M.; et al. Survival benefit of boron neutron capture therapy for recurrent malignant gliomas. J. Neurooncol. 2009, 91, 199-206. [CrossRef]

7. Kankaanranta, L.; Saarilahti, K.; Makitie, A.; Valimaki, P.; Tenhunen, M.; Joensuu, H. Boron neutron capture therapy (BNCT) followed by intensity modulated chemoradiotherapy as primary treatment of large head and neck cancer with intracranial involvement. Radiother. Oncol. 2011, 99, 98-99. [CrossRef]

8. Kankaanranta, L.; Seppälä, T.; Koivunoro, H.; Saarilahti, K.; Atula, T.; Collan, J.; Salli, E.; Kortesniemi, M.; Uusi-Simola, J.; Välimäki, P.; et al. Boron neutron capture therapy in the treatment of locally recurred head-and-neck cancer: Final analysis of a phase I/II trial. Int. J. Radiat. Oncol. Biol. Phys. 2012, 82, e67-e75. [CrossRef]

9. Ariyoshi, Y.; Miyatake, S.; Kimura, Y.; Shimahara, T.; Kawabata, S.; Nagata, K.; Suzuki, M.; Maruhashi, A.; Ono, K.; Shimahara, $\mathrm{M}$. Boron neuron capture therapy using epithermal neutrons for recurrent cancer in the oral cavity and cervical lymph node metastasis. Oncol. Rep. 2007, 18, 861-866. [CrossRef]

10. Kimura, Y.; Ariyoshi, Y.; Miyatake, S.; Shimahara, M.; Kawabata, S.; Ono, K. Boron neutron capture therapy for papillary cystadenocarcinoma in the upper lip: A case report. Int. J. Oral. Maxillofac. Surg. 2009, 38, 293-295. [CrossRef]

11. Kimura, Y.; Ariyoshi, Y.; Shimahara, M.; Miyatake, S.; Kawabata, S.; Ono, K.; Suzuki, M.; Maruhashi, A. Boron neutron capture therapy for recurrent oral cancer and metastasis of cervical lymph node. Appl. Radiat. Isot. 2009, 67, S47-S49. [CrossRef]

12. Aihara, T.; Hiratsuka, J.; Morita, N.; Uno, M.; Sakurai, Y.; Maruhashi, A.; Ono, K.; Harada, T. First clinical case of boron neutron capture therapy for head and neck malignancies using 18F-BPA PET. Head Neck 2006, 28, 850-855. [CrossRef] [PubMed]

13. Kato, I.; Ono, K.; Sakurai, Y.; Ohmae, M.; Maruhashi, A.; Imahori, Y.; Kirihata, M.; Nakazawa, M.; Yura, Y. Effectiveness of BNCT for recurrent head and neck malignancies. Appl. Radiat. Isot. 2004, 61, 1069-1073. [CrossRef] [PubMed]

14. Kato, I.; Fujita, Y.; Maruhashi, A.; Kumada, H.; Ohmae, M.; Kirihata, M.; Imahori, Y.; Suzuki, M.; Sakrai, Y.; Sumi, T.; et al. Effectiveness of boron neutron capture therapy for recurrent head and neck malignancies. Appl. Radiat. Isot. 2009, 67, S37-S42. [CrossRef] [PubMed]

15. Mishima, Y.; Honda, C.; Ichihashi, M.; Obara, H.; Hiratsuka, J.; Fukuda, H.; Karashima, H.; Kobayashi, T.; Kanda, K.; Yoshino, K Treatment of malignant melanoma by single thermal neutron capture therapy with melanoma-seeking ${ }^{10} \mathrm{~B}$-compound. Lancet 1989, 2, 388-389. [CrossRef]

16. Mishima, Y. (Ed.) Selective thermal neutron capture therapy of cancer cells using their specific metabolic activities-melanoma as prototype. In Cancer Neutron Capture Therapy; Plenum Press: New York, NY, USA, 1996; pp. 1-26.

17. Yong, Z.; Song, Z.; Zhou, Y.; Liu, T.; Zhang, Z.; Zhao, Y.; Chen, Y.; Jin, C.; Chen, X.; Lu, J.; et al. Boron neutron capture therapy for malignant melanoma: First clinical case report in China. Chin. J. Cancer Res. 2016, 28, 634-640. [CrossRef] [PubMed]

18. Hiratsuka, J.F. Malignant melanoma. In Neutron Capture Therapy; Sauerwein, W., Wittig, A., Moss, R., Nakagawa, Y., Eds.; Springer: Berlin/Heidelberg, Germany, 2012; pp. 433-448.

19. Hiratsuka, J.; Kamitani, N.; Tanaka, R.; Yoden, E.; Tokiya, R.; Suzuki, M.; Barth, R.F.; Ono, K. Boron neutron capture therapy for vulvar melanoma and extramammary Paget's disease of the genital regions with curative clinical responses. Chin. J. Cancer 2018, $38,1-10$.

20. Luderer, M.J.; Puente, P.; Azab, A.K. Advancements in tumor targeting strategies for boron neutron capture therapy. Pharm. Res. 2015, 32, 2824-2836. [CrossRef] [PubMed]

21. Brooks, W.L.A.; Sumerlin, B.S. Synthesis and applications of boronic acid-containing polymers: From materials to medicine. Chem. Rev. 2016, 116, 1375-1397. [CrossRef]

22. Kawasaki, R.; Sasaki, Y.; Akiyoshi, K. Intracellular delivery and passive tumor targeting of a self-assembled nanogel containing carborane clusters for boron neutron capture therapy. Biochem. Biophys. Res. Commun. 2017, 483, 147-152. [CrossRef] [PubMed]

23. Nomoto, T.; Inoue, Y.; Yao, Y.; Suzuki, M.; Kanamori, K.; Takemoto, H.; Matsui, M.; Tomoda, K.; Nishiyama, N. Poly(vinyl alcohol) boosting therapeutic potential of p-boronophenylalanine in neutron capture therapy by modulating metabolism. Sci. Adv. 2020, 6, eaaz1722. [CrossRef]

24. Yoneoka, S.; Nakagawa, Y.; Uto, K.; Sakura, K.; Tsukahara, T.; Ebara, M. Boron-incorporating hemagglutinating virus of Japan envelope (HVJ-E) nanomaterial in boron neutron capture therapy. Sci. Technol. Adv. Mater. 2019, 20, 291-304. [CrossRef]

25. Nakamura, H.; Ueda, N.; Ban, H.S.; Ueno, M.; Tachikawa, S. Design and synthesis of fluorescence-labeled closo-dodecaborate lipid: Its liposome formation and in vivo imaging targeting of tumors for boron neutron capture therapy. Org. Biomol. Chem. 2012, 10, 1374-1380. [CrossRef] [PubMed]

26. Bhushan, B.; Khanadeev, V.; Khlebtsov, B.; Khlebtsov, N.; Gopinath, P. Impact of albumin based approaches in nanomedicine: Imaging, targeting and drug delivery. Adv. Colloid Interface Sci. 2017, 246, 13-39. [CrossRef] [PubMed]

27. Kulluru, L.P.; Rizvi, S.A.; D'Souza, M.; D'Souza, M. Formulation development of albumin based theranostic nanoparticles as a potential delivery system for tumor targeting. J. Drug Target. 2013, 21, 77-86. [CrossRef] [PubMed]

28. Yhee, J.Y.; Lee, J.; Chang, H.; Jeewon, L.; Kwon, I.C.; Kim, K. Molecular imaging and targeted drug delivery using albumin-based nanoparticles. Curr. Pharm. Des. 2015, 21, 1889-1898. [CrossRef]

29. Elzoghby, A.O.; Samy, W.M.; Elgindy, S.N. Albumin-based nanoparticles as potential controlled release drug delivery systems. J. Control. Release 2012, 157, 168-182. [CrossRef] [PubMed]

30. Bolaños, K.; Kogan, M.J.; Araya, E. Capping gold nanoparticles with albumin to improve their biomedical properties. Int. J. Nanomed. 2019, 14, 6387-6406. [CrossRef] [PubMed] 
31. Larsen, M.T.; Kuhlmann, M.; Hvam, M.L.; Howard, K.A. Albumin-based drug delivery: Harnessing nature to cure disease. Mol. Cell. Ther. 2016, 4, 1-12. [CrossRef]

32. Schäffler, M.; Sousa, F.; Wenk, A.; Sitia, L.; Hirn, S.; Schleh, C.; Haberl, N.; Violatto, M.; Canovi, M.; Andreozzi, P.; et al. Blood protein coating of gold nanoparticles as potential tool for organ targeting. Biomaterials 2014, 35, 3435-3466. [CrossRef]

33. Brekken, R.A.; Sage, E.H.; Brekken, R.A. Mini review SPARC, a matricellular protein: At the crossroads of cell matrix SPARC, a matricellular protein: At the crossroads of cell matrix communication. Matrix Biol. 2001, 19, 815-827. [CrossRef]

34. Kouros, M. SPARC (osteonectin/BM-40). Int. J. Biochem. Cell Biol. 1999, 31, 1363-1366.

35. Podhajcer, O.L.; Benedetti, L.G.; Girotti, M.R.; Prada, F.; Salvatierra, E.; Llera, A.S. The role of the matricellular protein SPARC in the dynamic interaction between the tumor and the host. Cancer Metastasis Rev. 2008, 27, 691-705. [CrossRef] [PubMed]

36. Shi, Q.; Bao, S.; Song, L.; Wu, Q.; Bigner, D.D.; Hjelmeland, A.B.; Rich, J.N. Targeting SPARC expression decreases glioma cellular survival and invasion associated with reduced activities of FAK and ILK kinases. Oncogene 2007, 26, 4084-4094. [CrossRef] [PubMed]

37. Kikuchi, S.; Kanoh, D.; Sato, S.; Sakurai, Y.; Suzuki, M.; Nakamura, H. Maleimide-functionalized closo-dodecaborate albumin conjugates (MID-AC): Unique ligation at cysteine and lysine residues enables efficient boron delivery to tumor for neutron capture therapy. J. Control. Release 2016, 237, 160-167. [CrossRef] [PubMed]

38. Ishii, S.; Sato, S.; Asami, H.; Hasegawa, T.; Kohno, J.; Nakamura, H. Design of S-S bond containing maleimide-conjugated closo-dodecaborate (SSMID): Identification of unique modification sites on albumin and investigation of intracellular uptake. Org. Biomol. Chem. 2019, 17, 5496-5499. [CrossRef]

39. Nakamura, H.; Kikuchi, S.; Kaway, K.; Ishii, S.; Sato, S. closo-Dodecaborate-conjugated human serum albumins: Preparation and in vivo selective boron delivery to tumor. Pure Appl. Chem. 2018, 90, 745-753. [CrossRef]

40. Sato, S.; Ishii, H.; Nakamura, H. Development of albumin-closo-dodecaborate conjugates as boron carriers for neutron-capture therapy by Ru(bpy)3-photocatalyzed modification of tyrosine. Eur. J. Inorg. Chem. 2017, 2017, 4406-4410. [CrossRef]

41. Pulagam, K.R.; Gona, K.B.; Gómez-Vallejo, V.; Meijer, J.; Zilberfain, C.; Estrela-Lopis, I.; Baz, Z.; Cossio, U.; Llop, J. Gold nanoparticles as boron carriers for boron neutron capture therapy: Synthesis, Radiolabelling and in vivo evaluation. Molecules 2019, 24, 3609. [CrossRef] [PubMed]

42. Frigell, J.; García, I.; Gómez-Vallejo, V.; Llop, J.; Penadés, S. ${ }^{68}$ Ga-labeled gold glyconanoparticles for exploring blood-brain barrier permeability: Preparation, biodistribution studies, and improved brain uptake via neuropeptide conjugation. J. Am. Chem. Soc. 2014, 136, 449-457. [CrossRef]

43. Ishiwata, K. 4-Borono-2-18F-fluoro-L-phenylalanine PET for boron neutron capture therapy-oriented diagnosis: Overview of a quarter century of research. Ann. Nucl. Med. 2019, 33, 223-236. [CrossRef] [PubMed]

44. Savolainen, S.; Kortesniemi, M.; Timonen, M.; Reijonen, V.; Kuusela, L.; Uusi-Simola, J.; Salli, E.; Koivunoro, H.; Seppälä, T.; Lönnroth, N.; et al. Boron neutron capture therapy (BNCT) in Finland: Technological and physical prospects after 20 years of experiences. Phys. Med. 2013, 29, 233-248. [CrossRef] [PubMed]

45. Zhao, J.; Chen, J.; Ma, S.; Liu, Q.; Huang, L.; Chen, X.; Lou, K.; Wang, W. Recent developments in multimodality fluorescence imaging probes. Acta Pharm. Sin. B 2018, 8, 320-338. [CrossRef]

46. Louie, A. Multimodality imaging probes: Design and challenges. Chem. Rev. 2010, 110, 3146-3195. [CrossRef] [PubMed]

47. Ruiz-Cabello, J.; Barnett, B.P.; Bottomley, P.A.; Bulte, J.W. Fluorine ( $\left.{ }^{19} \mathrm{~F}\right) \mathrm{MRS}$ and MRI in biomedicine. NMR Biomed. 2011, 24, 114-129. [CrossRef]

48. Chubarov, A.S.; Zakharova, O.D.; Koval, O.A.; Romaschenko, A.V.; Akulov, A.E.; Zavjalov, E.L.; Razumov, I.A.; Koptyug, I.V.; Knorre, D.G.; Godovikova, T.S. Design of protein homocystamides with enhanced tumor uptake properties for ${ }^{19} \mathrm{~F}$ magnetic resonance imaging. Bioorg. Med. Chem. 2015, 23, 6943-6954. [CrossRef] [PubMed]

49. Lisitskiy, V.A.; Khan, H.; Popova, T.V.; Chubarov, A.S.; Zakharova, O.D.; Akulov, A.E.; Shevelev, O.B.; Zavjalov, E.L.; Koptyug, I.V.; Ahmad, S.; et al. Multifunctional human serum albumin-therapeutic nucleotide conjugate with redox and $\mathrm{pH}$-sensitive drug release mechanism for cancer theranostics. Bioorg. Med. Chem. Lett. 2017, 27, 3925-3930. [CrossRef]

50. Fasano, F.; Campanella, R.; Migneco, L.M.; Pastore, F.S.; Maraviglia, B. In vivo F-19 MRI and F-19 MRS of F-19-labelled borophenylalanine-fructose complex on a C6 rat glioma model to optimize boron neutron capture therapy (BNCT). Phys. Med. Biol. 2008, 53, 6979-6989.

51. Elsadek, B.; Kratz, F. Impact of albumin on drug delivery-New applications on the horizon. J. Control. Release 2012, 157, 4-28. [CrossRef]

52. Caspersen, M.B.; Kuhlmann, M.; Nicholls, K.; Saxton, M.J.; Andersen, B.; Bunting, K.; Cameron, J.; Howard, K.A. Albumin-based drug delivery using cysteine 34 chemical conjugates-important considerations and requirements. Ther. Deliv. 2017, 8, 511-519. [CrossRef]

53. Peters, T., Jr. The Albumin molecule: Its structure and chemical properties. In All about Albumin: Biochemistry, Genetics, and Molecular Applications; Academic Press: San Diego, CA, USA, 1996; p. 432.

54. Liu, Z.; Chen, X. Simple bioconjugate chemistry serves great clinical advances: Albumin as a versatile platform for diagnosis and precision therapy. Chem. Soc. Rev. 2016, 45, 1432-1456. [CrossRef] [PubMed]

55. An, F.-F.; Zhang, X.-H. Strategies for preparing albumin-based nanoparticles for multifunctional bioimaging and drug delivery. Theranostics 2017, 7, 3667-3689. [CrossRef] [PubMed] 
56. Popova, T.V.; Pyshnaya, I.A.; Zakharova, O.D.; Akulov, A.E.; Shevelev, O.B.; Poletaeva, J.; Zavjalov, E.L.; Silnikov, V.N.; Ryabchikova, E.I.; Godovikova, T.S. Rational design of albumin theranostic conjugates for gold nanoparticles anticancer drugs: Where the seed meets the soil? Biomedicines 2021, 9, 74. [CrossRef] [PubMed]

57. Wanigasekara, M.S.K.; Huang, X.; Chakrabarty, J.K.; Bugarin, A.; Chowdhury, S.M. Arginine-Selective chemical labeling approach for identification and enrichment of reactive arginine residues in proteins. ACS Omega 2018, 3, 14229-14235. [CrossRef] [PubMed]

58. Fuentes, E.; Araya-Maturana, R.; Urra, F.A. Regulation of mitochondrial function as a promising target in platelet activationrelated diseases. Free Radic. Biol. Med. 2019, 136, 172-182. [CrossRef]

59. Li, W.; Zhang, X.; Sang, H.; Zhou, Y.; Shang, C.; Wang, Y.; Zhu, H. Effects of hyperglycemia on the progression of tumor diseases. J. Exp. Clin. Cancer Res. 2019, 38, 327. [CrossRef] [PubMed]

60. Burrell, R.A.; McGranahan, N.; Bartek, J.; Swanton, C. The causes and consequences of genetic heterogeneity in cancer evolution. Nature 2013, 7467, 338-345. [CrossRef]

61. Turner, N.C.; Reis-Filho, J.S. Genetic heterogeneity and cancer drug resistance. Lancet Oncol. 2012, 13, 178-185. [CrossRef]

62. Xu, X.; Ho, W.; Zhang, X.; Bertrand, N.; Farokhzad, O. Cancer nanomedicine: From targeted delivery to combination therapy. Trends Mol. Med. 2015, 21, 223-232. [CrossRef]

63. Hu, C.M.; Zhang, L. Nanoparticle-based combination therapy toward overcoming drug resistance in cancer. Biochem. Pharm. 2012, 83, 1104-1111. [CrossRef]

64. Bregadze, V.; Sivaev, I.; Glazun, S. Polyhedral boron compounds as potential diagnostic and therapeutic antitumor agents. Anti-Cancer Agents Med. Chem. 2006, 6, 75-109. [CrossRef] [PubMed]

65. Ravasco, J.M.; Faustino, H.; Trindade, A.; Gois, P.M.P. Bioconjugation with maleimides: A useful tool for chemical biology. Chem. Eur. J. 2018, 24, 1-18. [CrossRef]

66. Janatova, J.; Fuller, J.K.; Hunter, M.J. The heterogeneity of bovine albumin with respect to sulfhydryl and dimer content. J. Biol. Chem. 1968, 243, 3612-3622. [CrossRef]

67. Jakubowski, H. Homocysteine in Protein Structure/Function and Human Disease: Chemical Biology of Homocysteine-containing Proteins; Springer: Wien, Austria, 2013; pp. 1-166.

68. Eriksson, U.J.; Borg, L.A. Protection by free oxygen radical scavenging enzymes against glucose-induced embryonic malformations in vitro. Diabetologia 1991, 34, 325-331. [CrossRef]

69. Pisanti, F.A.; Frascatore, S.; Vuttariello, E.; Grillo, A. Influence of acetyl homocysteine thiolactone on erythrocyte superoxide dismutase activity. Biochem. Med. Metab. Biol. 1987, 37, 265-267. [CrossRef]

70. Papaccio, G.; Pisanti, F.A.; Frascatore, S. Acetyl-homocysteine-thiolactone-induced increase of superoxide dismutase counteracts the effect of subdiabetogenic doses of streptozocin. Diabetes 1986, 35, 470-474. [CrossRef]

71. Mbiya, W.; Choi, B.; Martincigh, B.S.; Morakinyo, M.K.; Simoyi, R.H. Oxyhalogen-sulfur chemistry: Kinetics and mechanism of oxidation of $\mathrm{N}$-acetyl homocysteine thiolactone by acidified bromate and aqueous bromine. J. Phys. Chem. A 2013, 117, 13059-13069. [CrossRef] [PubMed]

72. Mosmann, T. Rapid colorimetric assay for cellular growth and survival-application to proliferation and cyto-toxicity assays. $J$. Immunol. Methods 1983, 65, 55-63. [CrossRef]

73. Bannunah, A.M.; Vllasaliu, D.; Lord, J.; Stolnik, S. Mechanisms of nanoparticle internalization and transport across an intestinal epithelial cell model: Effect of size and surface charge. Mol. Pharm. 2014, 11, 4363-4373. [CrossRef] [PubMed]

74. Martucci, N.M.; Migliaccio, N.; Ruggiero, I.; Albano, F.; Calì, G.; Romano, S.; Terracciano, M.; Rea, I.; Arcari, P.; Lamberti, A. Nanoparticle-based strategy for personalized B-cell lymphoma therapy. Int. J. Nanomed. 2016, 11, 6089-6101. [CrossRef]

75. Kreiner, A.J.; Bergueiro, J.; Cartelli, D.; Baldo, M.; Castell, W.; Asoia, J.G.; Padulo, J.; Sandín, J.C.S.; Igarzabal, M.; Erhardt, J.; et al. Present status of accelerator-based BNCT. Rep. Pract. Oncol. Radiother. 2016, 21, 95-101. [CrossRef]

76. Taskaev, S. Development of an accelerator-based epithermal neutron source for boron neutron capture therapy. Phys. Part. Nucl. 2019, 50, 569-575. [CrossRef]

77. Sato, E.; Zaboronok, A.; Yamamoto, T.; Nakai, K.; Taskaev, S.; Volkova, O.; Mechetina, L.; Taranin, A.; Kanygin, V.; Isobe, T.; et al. Radiobiological response of U251MG, CHO-K1 and V79 cell lines to accelerator-based boron neutron capture therapy. J. Radiat. Res. 2018, 59, 101-107. [CrossRef]

78. Zaboronok, A.; Byvaltsev, V.A.; Kanygin, V.V.; Iarullina, A.I.; Kichigin, A.I.; Taranin, A.V.; Volkova, O.Y.; Mechetina, L.V.; Taskaev, S.Y.; Muhamadiyarov, R.A.; et al. Boron-neutron capture therapy in Russia: Preclinical evaluation of efficacy and perspectives of its application in neurooncology. New Armen. Med. J. 2017, 11, 6-15.

79. Franken, N.A.P.; Rodermond, H.M.; Stap, J.; Haveman, J.; van Bree, C. Clonogenic assay of cells in vitro. Nat. Protoc. 2006, 1, 2315-2319. [CrossRef] [PubMed]

80. Sivaev, I.B.; Semioshkin, A.A.; Brellochs, B.; Sjoberg, S.; Bregadze, V.I. Synthesis of oxonium derivatives of the dodecahydro-closododecaborate anion $\left[\mathrm{B}_{12} \mathrm{H}_{12}\right]^{2-}$. Tetramethylene oxonium derivative of $\left[\mathrm{B}_{12} \mathrm{H}_{12}\right]^{2-}$ as a convenient precursor for the synthesis of functional compounds for boron neutron capture therapy. Polyhedron 2000, 19, 627-632. [CrossRef] 